\title{
Digital technologies and their impact on the innovative development of the region
}

\author{
Tamara Egorovna Rodina* \\ Bryansk state engineering-technological University, Lenin Str., 26a, 241000 Bryansk, Russia
}

\begin{abstract}
The article discusses the processes of digitalization of the economy at the regional level. The subject of the research is the work of the region to find opportunities for implementing digital technologies in various fields of activity. Research methods-analysis and synthesis, tabular, historical past. The significance of the introduction of digital technologies as a factor of self-development of the region is proved. The article substantiates the need to create conditions for improving the quality of education through the development of online courses in the framework of the project "Modern digital educational environment". The practical significance is to identify the problems and prospects of testing digital technologies in the development of the region's economy.
\end{abstract}

\section{Introduction}

The development of the digital economy is a priority and one of the most significant trends in the modern world. In Russia, the term "digital economy" received an official state definition in 2017, which is reflected in the country's information society development Strategy. First of all, the digital economy is considered from the point of view of forming new markets based on the use of ICT, which will strengthen the growth of the Russian economy on the basis of high-tech industries and industries, available opportunities.

At the present stage of development of the Russian Federation, issues of economic and financial security of regions are becoming a priority [1]. The Bryansk region has sufficient strategic opportunities for development in the context of digitalization. Industry, agriculture, transport and telecommunications are well developed in the region. Products of regional enterprises are in high demand both in the region and abroad.

The Bryansk region is actively working to implement the main platforms of the Federal project "Digital economy of the Russian Federation".

The main customer of such events is the Ministry of digital development, communications and mass communications of the Russian Federation. On the territory of the Bryansk region, the implementation of the idea is determined to be carried out by PJSC Rostelecom.

The government of the Bryansk region, in accordance with the powers assigned by the Ministry, provides comprehensive support to the regional Telecom operator.

The regional project is of great social significance for residents of localities, since the

*Corresponding author: ribnikoff@yandex.ru 
availability of communications will ensure the development of the network for individuals and legal entities in the near future.

The result of this work is the connection to the network of the school and FAPA in the village of Novoe Kaplino, Zhiryatinsky district, together with the Bryansk branch of PJSC Rostelecom.

High information technologies allow changing business processes in other sectors of the economy $[2,3]$. According to official data, the labor market is experiencing a shortage of employees with it skills. Companies ' need for it specialists is growing rapidly.

In this regard, the introduction of digital educational platforms is an important and urgent task. Online education can become both basic and additional, this is due to the fact that it involves a convenient, flexible schedule and the ability to take courses from anywhere in the world at any time of the day.

Whether all these trends are advantages or disadvantages for online education is up to each student to decide for themselves, but it is clear that science and online education are significantly ahead of classical education in terms of technology.

High information technologies allow changing business processes in other sectors of the economy $[4,5]$. The labor market is experiencing a shortage of employees with it skills. Companies ' need for it specialists is growing rapidly.

Statistics show that the share of relevant ads on HeadHunter increased by $6 \%$ between 2016 and 2018 alone. However, demand outstrips supply. According to the estimates of analysts, to meet the needs of the market in it personnel, it is necessary to increase the recruitment and graduation of students of the relevant specialties by at least 2.5 times. This trend is also confirmed by the goals of national projects. In accordance with the task, by 2024, universities should offer the market 120 thousand rubles. graduates in the field of it, the proportion of the population with digital skills should be $40 \%$.

In this regard, the introduction of digital educational platforms is an important and urgent task. This area of work includes not only the process of optimizing the educational process, but also a lot of work on the development of digital platforms [6]. Today, teenagers are more adapted to the introduction of new modern technologies, at the same time, their parents and teachers have to master electronic services. A qualitative example is the exercises in the electronic "Yandex.Textbook». Tasks are set by 37 thousand teachers and solved by 600 thousand students. Indeed, digital tools can make learning more effective, allowing you to discover the abilities of each individual child.

In addition, the experience of acquiring knowledge in the online system shows children that the computer is not only cartoons and games, but also an opportunity to learn.

It companies also help solve the personnel problem to a certain extent. They open laboratories, basic departments and entire faculties in higher education institutions, which helps to reduce the gap between theory and practice. School educational projects of specific companies are also being implemented, in particular, for example, "Yandex.Lyceum", where children are taught to program in Python.

Of course, a lot of work is being done in various areas. However, even with the assistance of representatives of educational institutions, the needs of the digital economy will not be fully met soon. The educational system is quite conservative, and this is a normal phenomenon.

In comparison with other countries of the world, in our country, employers pay much less attention to the higher education of applicants, for example, than in America. Young professionals in employment rarely limit their specialization in search of a job. According to VTsIOM, about $48 \%$ of Russian specialists work outside their specialty. 


\section{Materials and Methods}

According to the materials of the Federal project "Personnel for the digital economy", which is an integral part of the national program "Digital economy", the total cost of implementing the relevant measures in 2019-2021 will amount to 50.7 billion rubles.a significant part - over 46 billion rubles - will be provided from the Federal budget. Most of the activities included in this Federal project will be fully funded from the Federal budget [7].

In most cases, the curators of these events will be the Ministry of economic development, the Ministry of education or the Ministry of Education.

According to calculations, the most expensive event will be the creation of a network of international scientific and methodological centers aimed at spreading the best international practices in training personnel in the field of the digital economy.

7.4 billion rubles will be allocated from the Federal budget for the implementation of this direction. The performers will be the Global universities Association and the Association of leading Russian universities.

The Federal budget will allocate 6.2 billion rubles to create a network of centers based on higher education institutions aimed at developing "Digital University" models using digital technologies.

The costs of the Federal project "Personnel for the digital economy" of the national program "Digital economy" for the implementation of individual tasks for 2019-2021 are shown in table 1.

Table 1. Expenditures of the Federal project "Personnel for the digital economy" of the national program "Digital economy" for the implementation of certain tasks for 2019-2021, million rubles.

\begin{tabular}{|c|c|c|c|c|c|c|}
\hline \multirow[b]{2}{*}{ Areas of activity } & \multirow[b]{2}{*}{$\begin{array}{c}\text { Total } \\
\text { cost }\end{array}$} & \multicolumn{2}{|c|}{ Sources } & \multicolumn{3}{|c|}{ Cost } \\
\hline & & $\begin{array}{l}\text { federal } \\
\text { budget }\end{array}$ & $\begin{array}{l}\text { extra- } \\
\text { budgetary } \\
\text { funds }\end{array}$ & 2019 & 2020 & 2021 \\
\hline $\begin{array}{l}\text { Creating conditions for the support and } \\
\text { development of talented youth }\end{array}$ & 22528 & 22528 & - & 3755 & 6615 & 12158 \\
\hline $\begin{array}{l}\text { Creating conditions in the education system for } \\
\text { training competent specialists }\end{array}$ & 7802 & 3402 & 4400 & 1022 & 2805 & 3975 \\
\hline $\begin{array}{l}\text { Introduction of a system of additional } \\
\text { professional education for citizens }\end{array}$ & 5944 & 5929 & 15 & 1615 & 2199 & 2130 \\
\hline $\begin{array}{l}\text { Creating conditions for the implementation of } \\
\text { leading educational projects }\end{array}$ & 5932 & 5932 & - & 1500 & 1500 & 2932 \\
\hline $\begin{array}{l}\text { Providing assistance to citizens, including older } \\
\text { people, in mastering the competencies of the } \\
\text { digital economy }\end{array}$ & 3034 & 3019 & 15 & 478 & 454 & 2102 \\
\hline $\begin{array}{l}\text { Implementation of the requirements of key } \\
\text { competencies }\end{array}$ & 3000 & 2960 & 40 & 1195 & 340 & 1465 \\
\hline $\begin{array}{l}\text { Development and testing of personal profiles of } \\
\text { citizens ' competencies }\end{array}$ & 874 & 874 & - & 501 & 361 & 12 \\
\hline $\begin{array}{l}\text { Development and testing of the concept of } \\
\text { competencies for effective interaction between } \\
\text { business, education and society }\end{array}$ & 644 & 644 & - & 325 & 244 & 75 \\
\hline $\begin{array}{l}\text { Providing motivation for highly qualified foreign } \\
\text { citizens }\end{array}$ & 458 & 458 & - & 244 & 214 & 0 \\
\hline $\begin{array}{l}\text { Ensuring the functioning of the competence } \\
\text { center for solving Federal project tasks }\end{array}$ & 154 & 154 & - & 50 & 49 & 55 \\
\hline
\end{tabular}


Continuation of Table 1. Expenditures of the Federal project "Personnel for the digital economy" of the national program "Digital economy" for the implementation of certain tasks for 2019-2021, million rubles.

\begin{tabular}{|l|c|c|c|c|c|c|}
\hline $\begin{array}{l}\text { Enabling the use of competence profiles and } \\
\text { personal development trajectories }\end{array}$ & 142 & 142 & - & 112 & 30 & 0 \\
\hline $\begin{array}{l}\text { Development and testing of a mechanism for } \\
\text { independent assessment of citizens ' } \\
\text { competencies in the education system and labor } \\
\text { market }\end{array}$ & 105 & 105 & - & 45 & 60 & 0 \\
\hline $\begin{array}{l}\text { Implementation of digital economy tasks in the } \\
\text { qualification requirements of employees }\end{array}$ & 85 & 85 & - & 19 & 32 & 34 \\
\hline
\end{tabular}

Considerable attention is paid to the implementation of the national program "Digital economy" at the regional level.

A digital economy cluster has been created in the Bryansk region to implement the state policy and operation of the region's information technology companies. The agreement on its creation was signed between the Bryansk regional business incubator and the enterprises of the new structure.

The cluster is aimed at implementing complex projects to find partners and clients among the members of the Association. It provides well-coordinated work aimed at developing the region's digital economy and small and medium-sized businesses.

\section{Results and Discussion}

Everyone interested in implementing complex and interesting technologies is interested in developing a digital economy cluster in the Bryansk region [8]. They are representatives of both small and medium-sized businesses, as well as large companies and universities in the region. The cluster currently has ten companies in the region: industrial structures, hightech enterprises and organizations, and educational institutions.

For students at cluster enterprises, it is necessary to organize an industrial practice. Educational activities of the cluster are designed more for students.

Creating conditions for the sustainable development of the digital economy cluster in the Bryansk region requires effective interaction between participating companies. It is necessary to promote effective interaction of participants in the field of web development. The main representatives of the cluster in the field of web development-IP Ananyin A.V., IP Malygin N. O. when implementing the strategy should interact with each other to solve common problems of market promotion and reaching larger customers.

A virtual brand is an Association of web developers of cluster companies under a common name that allows them to be quoted in industry ratings and receive larger orders.

Commercial projects - the launch of joint Internet projects (online stores, services), in which the profit of web developers appears as a result of the commercialization of Internet projects, and not as a payment for development.

Cluster companies can rely on the use of two existing trends to advance to the Russian market:

- import substitution - the policy of replacing foreign software systems, electronic components and equipment used in the management of technological processes in significant sectors of the economy;

- investment in agriculture-the trend of investment growth against the background of import restrictions, which increases the size of the market for automation of agricultural facilities and creates opportunities for cluster participants.

It is planned to implement several ways of promotion: comprehensive proposals for the 
formation of commercial offers to large customers by combining the competencies of several web developers in the cluster.

The second direction is Internet marketing: development and support of advertising companies on the Internet. Yandex.Direct and Google Adwords. Configuring CRM systems

Creating a Cluster means increasing tax revenues to the budget of the Bryansk region, expanding the number of jobs at small and medium-sized businesses.

Office technologies LLC has the strongest competencies and market positions in the digital industry. Thousands of people have become users of the company over 10 years of operation on the market. Automation systems developed by Office technologies LLC allow you to automate any organization:

- large multi-branch organizations;

- small and medium-sized enterprises;

- unified e-health system in the region.

The products of Office technologies LLC are successfully used for automation of more than 100 corporate clients - public and private medical organizations, public and private pharmaceutical networks and pharmacies, educational institutions:

- specialists of Office technologies LLC and Rusbitech-Astra LLC conducted joint test tests for compatibility and correct operation of computer software products;

- Office technologies LLC, in partnership with Rostelecom, is implementing a project to automate the University clinic at Oryol state University, etc.

The implementation of management systems increases the efficiency of personnel at any level-from ordinary employees to managers.

In order to intensively implement digital technologies and platform solutions in the agricultural sector of Russia, the Ministry of agriculture is implementing the departmental project "Digital agriculture", designed for 2019-2024.

During the course of the year, the Ministry of agriculture of Russia plans to launch the smart contract concept to formalize contracts with grant recipients during the implementation of the plan for 2019-2024. It is planned to introduce domestic integrated digital agricultural solutions everywhere. Among them, the most popular are "Smart greenhouse", "Smart farm", "Smart field", "Smart herd", "Smart agrooffice". Previously, more than 35 regions of the Russian Federation actively participate in the Ministry of agriculture's Digital agriculture project.

Thus, the availability of such software products is popular among the society and effectively affects the performance of functions by public authorities [9].

Innovative technologies for the development of the agricultural sector suggest that information and communication technologies will be used [10].

Two platforms can become key and complementary for digital ecosystems in the field of agricultural business: "Technologies of the food and processing industry" and "Eurasian agricultural technology platform". In addition, other complementary technologies can be applied - "Space and geoinformation technologies-products of global competitiveness" and others.

Today, some Russian agricultural complexes successfully use the latest technological processes of farming in animal husbandry and crop production. In the Bryansk region, for example, the latest technologies in vegetable growing are being successfully introduced [11]. They were discussed at the international agricultural exhibition "day of the Bryansk field", at the Slavic international economic forum.

The Moscow region applies the reconstruction of farms with the introduction of the latest technologies for keeping, feeding and milking animals, as well as the introduction of energy-saving agriculture. Thanks to high technologies, it became possible to freely maintain housing for cattle. Individual farms (for example, enterprises of the Krasnodar territory, the Republic of Tatarstan, Belgorod, Rostov, Kursk and other regions) have 
significantly succeeded in the so-called arable farming, having built livestock complexes of the highest level.

In 2018, the law on organic agriculture was adopted, which provides farmers with excellent opportunities not only to work in the domestic market, but also to win over foreign consumers.

It is advisable to form the budgets of cluster companies taking into account their orientation (and differentiation) for the purposes of operating activities and project financing. The main principle of promoting the development of clusters on the part of the authorities is trust in the decisions made by the cluster participants both in terms of managing its development and in justifying certain projects.

The operational activities of cluster companies in conditions of a lack of trust between their participants should be guaranteed by the allocation of budget funds.

Creating a platform for fruitful interaction between cluster members and forming trusting relationships between them is a basic condition for intra-cluster cooperation, which determines priorities and the sequence of actions.

The main results of the cluster development strategy implementation are shown in table 16 and relate to possible growth scenarios for the main activities of the cluster member companies.

Three scenario scenarios for cluster development with the following average annual growth rates are proposed: conservative - less than $10 \%$; moderate - up to $20 \%$; target-up to $40 \%$ (Table 2).

Table 2. Main effects of implementing the cluster strategy.

\begin{tabular}{|l|c|c|c|c|}
\hline & \multirow{2}{*}{ Indicator } & \multirow{2}{*}{$\begin{array}{c}\text { Actual } \\
\text { value }\end{array}$} & $\begin{array}{c}\text { The value of the indicator for the } \\
\text { years 2019-2022 }\end{array}$ \\
\cline { 3 - 5 } & & $\begin{array}{c}\text { Conservati } \\
\text { ve } \\
\text { scenario }\end{array}$ & $\begin{array}{c}\text { Moderate } \\
\text { scenario }\end{array}$ & $\begin{array}{c}\text { Target } \\
\text { scenario }\end{array}$ \\
\hline $\begin{array}{l}\text { The number of personnel involved in the field of } \\
\text { web development, people }\end{array}$ & 10 & 11 & 12 & 14 \\
\hline $\begin{array}{l}\text { Number of personnel employed in the field of } \\
\text { automated process control, people }\end{array}$ & 66 & 72 & 79 & 92 \\
\hline $\begin{array}{l}\text { Number of employees engaged in business } \\
\text { programming and information technology } \\
\text { infrastructure, people }\end{array}$ & 84 & 92 & 100 & 117 \\
\hline $\begin{array}{l}\text { The total number of staff employed in the } \\
\text { companies of the Cluster, people }\end{array}$ & 160 & 175 & 191 & 223 \\
\hline
\end{tabular}

The basis for calculations is the number of employees involved in the main areas of cluster activity. The output per employee is calculated at the rate of 1 million rubles / person per year, which includes salary with deductions, the company's costs for organizing the workplace, purchasing equipment, overhead costs, taxes, and enterprise profit.

The implementation of the functional strategy for the development of the digital economy cluster in the Bryansk region is aimed at the following activities:

1. Development and coordination of the current development plan (directions).

2. Implementation of communication functions.

3. Defining the format of management and participation in joint projects.

4. Formation of budgets of cluster companies, taking into account the differentiation for the purposes of operating activities and project financing. 


\section{Conclusions}

Digitalization of business processes will enable Russian businesses to move to a new stage of their development and provide them with long-term competitive advantages [12]. In addition, activities aimed at large-scale practical implementation of digital technologies and acceleration of modernization, development of domestic practical experience in priority sectors of the economy have been intensified [13].

1. Analysis of the activities of regional IT companies has shown great potential in the information and communication sector of the Bryansk region. Both large companies and small and medium-sized businesses that develop software operate in the region, but the Bryansk region is characterized by insufficient development of information networks. The development of the information and communication technologies sector is hindered by low demand for products and services from the state, organizations and the population. In particular, the demand for providing state and municipal services in electronic form is highly estimated by regional experts, and this is the second most important opportunity after increasing the availability of mobile communications and the Internet in the Bryansk region.

2. A significant part of the identified problems can be solved on the basis of state support, implementation of effective IT projects, expansion of the information field about the demand for specific products on the national market, and reduction of administrative barriers. In the business sector, it is also important to build up knowledge and experience.

3 . It is necessary to create conditions that will ensure sustainable economic growth, create high-performance jobs and accumulate opportunities for the development and implementation of digital transformation projects. To this end, a program for creating and developing a digital economy cluster has been developed.

4. The digital economy cluster of the Bryansk region is in the initial stage of development. Information interaction between the participants has been established, but its coverage is insufficient, and constructive cooperation with the regional authorities has been established. There is practically no necessary link for the cluster-the scientific base. Interaction with educational institutions is developing quite actively. The existing cluster chains are still few and the principles of intra-cluster cooperation need to be streamlined, and cluster management needs to be developed.

The project will allow the cluster to the digital economy of the Bryansk region to obtain synergetic effect from the cooperation of the involved enterprises, reflected in the economic growth of cluster members and increase the efficiency of their functioning, obtaining economic benefits to all participants, improve the social climate in the region, as well as receiving the Bryansk region budget effect due to the growth of the tax base.

\section{Acknowledgements}

The article has been prepared as part of the research work of the Bryansk state University of engineering and technology, contract No. 171 of 25.11.2019.

\section{References}

1. M. A. Sabelnikova, G. I. Abdrakhmanova, L. M. Gokhberg, O. Yu. Dudorova et al., Information society: main characteristics of the subjects of the Russian Federation (2018)

2. G. Cainelli, V. Marchi, R. Grandinetti, Economics of innovation and new technology, $48(2020)$ 
3. M. Faravelli, K. Kalayci, C. Pimienta, Experimental economics, 468 (2020)

4. K. Williams, Economia, 404 (2018)

5. O. Afonso, P.C. Neves, T. Pinto, Economic systems (2020)

6. G.I. Abdrakhmanova, K.O. Vishnevsky, L.M. Gokhberg et al.; Indicators of the digital economy (2019)

7. V.L. Abashkin, S.V. Artemov, E.A. Islankina, etc.; Cluster policy: achieving global competitiveness (2017)

8. Website of the Bryansk region administration, http://www.bryanskobl.ru/

9. S.Y. Glazyev, Great and the digital economy, http://www.nlr.ru/

10. A. Chursin, A. Tyulin, Springer International Publishing (2018)

11. E. Islankina, T. Thurner, Entrepreneurship \& Regional Development (2018)

12. On the strategy for the development of the information society in the Russian Federation for 2017-2030: decree of the President of the Russian Federation, http://www.consultant.ru/

13. A. Jacqueminet, L. Trabelsi, Advances in strategic management, 169 (2018) 